\title{
PATULIN IN FOOD: STATE-OF-THE-ART AND ANALYTICAL TRENDS
}

\author{
SANDRA JUSSARANUNES DA SILVA ${ }^{1}$, PAULAZILLES SCHUCH ${ }^{2}$, CARMEM RONISE BERNARDI $^{3}$, MARILENE HENNING \\ VAINSTEIN $^{4}$, ANDRÉ JABLONSKI $^{5} \&$ RENAR JOÃOBENDER 6
}

\begin{abstract}
Patulin is a mycotoxin produced by several fungal species of the genera Penicillium and Aspergillus, found on several fruit species and, remarkably, in apples and apple products. Patulin has a broad spectrum of toxicity, including carcinogenicity and teratogenicity in animals. Due to the stability of the molecule, considerable amounts of patulin still remain in apple products after processing. This paper reviews different analytical methods for patulin determination and methods to reduce levels of patulin in apple products as well.
\end{abstract}

Index Terms: Micotoxins, analytical methods, apple

\section{PATULINA EM ALIMENTOS: ESTADO DAARTE E TENDÊNCIAS ANALÍTICAS}

RESUMO-A patulina é uma micotoxina produzida por diversas espécies de fungos dos gêneros Penicillium e Aspergillus, encontrada em diversas espécies frutíferas e, notadamente, em maçãs e produtos derivados da maçã. A patulina tem um amplo espectro de toxicidade, incluindo carcinogenicidade e teratogenicidade em animais. Devido a sua estabilidade, níveis consideráveis de patulina permanecem nos produtos derivados da maçã, mesmo após as etapas do processamento. Este artigo revisa os diferentes métodos analíticos usados para a determinação de patulina e métodos empregados para reduzir os níveis de patulina nos produtos alimentícios. Termos para Indexação: Micotoxina, métodos analíticos, maçã.

\section{INTRODUCTION}

Apples are the most world-wide commercialized temperate zone fruits. According to FAO (2006), more than 62 million tons of apples were produced in the 2005 season. Brazil occupied the thirteenth position in the ranking harvesting about 850 thousand tons. The states of Santa Catarina and Rio Grande do Sul concentrate more than $94 \%$ of the Brazilian apple production (IBGE, 2007). Almost all of the Brazilian production is based on two cultivars: Gala and Fuji and their various mutations (Kreuz \& Argenta, 2003).

The evolution of the apple production in Brazil is notable. From an importing country Brazil turned into become an exporter, though only 10 to $20 \%$ of the national production is exported, especially to Europe (Sanhueza, 2003). The necessity to implement and optimize fast and efficient methods for quality control of fruits and industrialized products appears as a consequence of this evolution.

The presence of fungi might compromise not only the quality of the apples, but also the quality of the industrialized products. Some fungi like Aspergillus, Penicillium, Fusarium, Clavices,
Alternaria, Pithomices and Stachybotrys have the ability to produce toxins. Mycotoxins such as aflatoxins, ochratoxin, zearalenon, trichothecenes, fumosins and patulin (Bennett, 1987; Dhingra \& Coelho Neto, 1998; Russell et al., 2004) may cause health problems to humans. Normally, several genera of fungi coexist in the same surroundings producing different toxins. The effect of the toxins become synergistic and has bigger impact when compared to the isolated effects. Therefore, aparently low individual toxin levels become important when combined with other ones (Bennett \& Klich, 2003).

The main natural mycotoxins produced in rotten apples were patulin and aflatoxins (Hasan, 2000). The presence of patulin in apples and derivatives on the Brazilian market has not been well studied yet. In the Southern region, where most of the apple production is concentrated, there are no exact data about the occurrence of toxins.

Patulin (g-lactone a-b insaturated \{4-hydroxy-4H-furol [3,2c] pyran-2(6H)-one $\}$ ) is a secondary metabolite naturally produced by a variety of fungi like Aspergillus, Penicillium and Byssochlamys. Even though patulin is frequently associated with Penicillium expansum, many other fungi having IDH

\footnotetext{
Ph.D. in Organic Chemistry-Laboratório de Fungos de Importância Médica e Biotecnólogica , Centro de Biotecnologia, Universidade Federal do Rio Grande Sul , Brazil - e-mail: sandrajussara2005@yahoo.com.br

${ }^{2}$ Undergraduate student - Universidade Federal do Rio Grande do Sul , Brazil- e-mail: paulaschuch@gmail.com

${ }^{3}$ Ph.D. in Organic Chemistry - ISCA Technologies, Riverside, CA, USA - e-mail: carmem.b@iscatech.com

${ }^{4} \mathrm{Ph} . \mathrm{D}$. in Biochemistry and Microorganisms Molecular Genetic - Laboratório de Fungos de Importância Médica e Biotecnólogica , Centro de Biotecnologia, Universidade Federal do Rio Grande Sul, Brazil- e-mail: mhv@cbiot.ufrgs.br

${ }^{5}$ Ph.D. in Organic Geochemistry - Laboratório de Geoquímica Ambiental, Escola de Engenharia, Universidade Federal do Rio Grande do Sul, Brazil e-mail: ajabba@terra.com.br

${ }^{6}$ Ph.D. in Horticultural Sciences/Postharvest Physiology - Laboratório de Pós-Colheita da Faculdade de Agronomia, Universidade Federal do Rio Grande do Sul, Brazil- e-mail: rjbe@vortex.ufrgs.br
} 
(isoepoxydon dehydrogenase) gene, which is essential to the biosynthesis of this toxin, may produce the toxin (Russell \& Paterson, 2006). Patulin is frequently found in apples, apple juices and other from apples processed products. Patulin was also detected in barley, wheat, corn, pears, peaches, other fruits and their derived processed products. (Frank, 1977; Bartolomé, 1994; Li et al., 2007).

Initially patulin was described as an antibiotic because of a strong activity against different gram-positive and gram-negative bacteria including Mycobacterium tuberculosis (Russell et al., 2004). Several researches reported the toxicity, mutagenicity and immunotoxicity of patulin, despite beeing classified in group 3 by IARC (International Agency for Research on Cancer) for lacking of evidences of its carcinogenicity in experiments with animals and humans (Alves et al., 2000; Wu et al., 2005; Schumacher et al., 2006; Selmanoglu, 2006). One of these studies reported that the ingestion of water contaminated with patulin at a concentration of $295 \mathrm{mg} . \mathrm{L}^{-1}$ during four weeks affected the gastrointestinal system in rats, causing ulcers (Speijers et al., 1988). Patulin cellular infiltration in rats at doses varying from 28 to $41 \mathrm{mg} . \mathrm{kg}^{-1}$ produced, in two weeks of experiment, lesions in the gastrointestinal tissues, including degeneration, hemorrhage, and ulceration of the gastric mucosa (McKinley et al., 1982). Mahfoud et al. (2002) found that micromolar concentrations of patulin induce a rapid and dramatic damage in human epithelial intestinal cells.

The concern of governments and researches, in general, has significantly risen in the last years due to the high occurrence of patulin, mainly in apples and from apples processed products. Several countries have established limits of $50 \mathrm{mg} \cdot \mathrm{kg}^{-1}$ in apple juices. This threshold is considered safe by the World Health Organization (WHO, 1998). Ingestion of patulin in high levels can cause serious damages to human health, particularly in children (Prieta et al., 1994). The chronic effects of patulin in humans are not well known. However, acute symptoms were observed after the ingestion, as perturbation, convulsion, ulceration, edema, intestinal inflammation, nauseas and vomit (Speijers, 2004).

\section{STRUCTURE, REACTIVITYANDSTABILITY}

Patulin is stable in low $\mathrm{pH}$ media and resistant to thermal denaturation. These properties turn its removal very difficult through pasteurization, for example (Dombrink-Kurtzman \& Blackburn, 2005). Some studies showed that patulin is eliminated during fermentation (Altmayer et al., 1982). However, its presence is diminished by only $20 \%$ during the process of juice extraction (Stray, 1978). Alternative methods to remove patulin, like irradiation or treatment with activated charcoal are not very efficient and diminish consumer acceptance (Zegota et al., 1988; Huebner et al., 2000). The chemical structure of patulin is shown in Figure1.

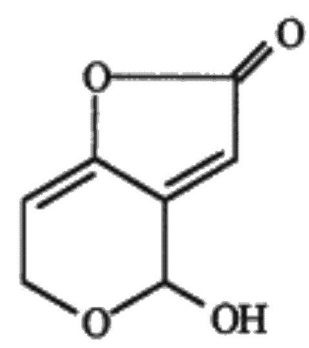

FIGURE 1 - Structure of Patulin (4-Hydroxy-4H-furol [3,2-c] pyran-2(6H)-one).

Studies showed that patulin is significantly reduced in apple juices when clarification processes are carried out (Bissessur et al., 2001). The total reduction of toxin using centrifugation, bentonite filtration, enzymatic treatment and filtration with filter paper was $89,77,73$ and $70 \%$, respectively. These processes resulted in high levels of patulin in the pressured pulp after filtration and centrifugation, which might be harmful if the pulp is used for animal feeding.

Patulin was reported to promptly react with sulfur dioxide $\left(\mathrm{SO}_{2}\right)$. So it could be destroyed when an antioxidant or antimicrobial agent containing sulfur dioxide is used (Roland \& Beuchat, 1984). The fortification with ascorbic acid also showed to be an efficient method to reduce the levels of the toxin (Brackett \& Marth, 1979; Drusch et al., 2007), as well as the addition of thiamine, pyridoxine and calcium pantotenate (Yazici \& Velioglu, 2002).

The biological activity of patulin is diminished in basic $\mathrm{pH}$ and in presence of molecules that connect to the sulfur group as cisteine and glutathion. Moreover, patulin is capable of crossbonding with proteins (Flieghe \& Metzler, 2000). Analysis of not clarified apple juices showed that patulin levels decrease with time, resulting from an interaction of patulin and the solid parts of juices, which contain more proteins that the liquid phase (Baert et al., 2007).

\section{OCURRENCE OF PATULIN IN FRUITS}

Patulin is frequently found in apples, pears, their juices and jams and other products derived from these fruits (Kawashima et al., 2002). It was also detected in other fruits, like grapes, cherries, plums, blueberries, oranges, strawberries and melons (Frank, 1977; Bartolomé, 1994; Li et al., 2007). It was found in fruits that exhibited brown rot, such as bananas, pineapples, grapes, peaches, and apricots, indicating that the use of decayed fruits for processing would lead to the presence of the toxin in the products (Frank et al., 1977). Fungal growth and the production of patulin are common in damaged fruit. However, patulin can also be detected in visualy sound fruit (Jackson et al., 2003).

Several studies have reported the contamination of patulin in 
apple juices in different countries, including Australia, Austria, Belgium, Brazil, Canada, France, Iran, Italy, Japan, South Africa, Spain, Sweden, United Kingdom, United States and Turkey (Spadaro et al., 2007).

In Brazil, Sylos \& Rodriguez-Amaya (1999) analyzed 111 samples of processed fruit juices and 38 samples of fresh fruit. Only one juice sample was contaminated with levels of $17 \mathrm{mg} . \mathrm{L}^{-1}$. However, levels varying from 150 to $167 \mathrm{mg} . \mathrm{kg}^{-1}$ of patulin were found in 14 samples of fresh fruit. Ross et al. (1998) studied the production of patulin in cv. Gala and cv. Fuji apples inoculated with Penicillium spp. The authors observed patulin production not only in conditions of storage at room temperature, but also in refrigerated samples. Prado et al. (2000) analyzed 13 trade brands of apple juices commercialized in Belo Horizonte, Brazil, and patulin (10 $\left.\mu \mathrm{g} . \mathrm{L}^{-1}\right)$ was detected in only one sample. In the state of Parana, Machinski \& Midio (1996) analyzed samples of industrialized apple juices and out of 76 samples, 15 contained patulin in levels ranging from 6 to $77 \mu \mathrm{g} . \mathrm{L}^{-1}$.

\section{METHODS OF ANALYSIS}

\section{Extraction and Purification}

Several conditions interfere in the determination of patulin levels in foods turning the quantification more difficult, for example, the non-homogeneous distribution of the toxin in samples and, sometimes, the very low levels of contamination of samples. Therefore the different steps in the process of extraction and purification of samples are necessary. Another important factor to be considered is that patulin in unstable in high $\mathrm{pH}$, limiting certain pre-treatment operations of samples (Taniwaki et al., 1992; Rychlik \& Schieberle, 2001; Boonzaaijer et al., 2005).

With the objective to guarantee an extraction of the patulin from food matrices, some solvents have been used. The purification of the final extract has the purpose of removing impurities from the matrix and to concentrate patulin. The selection of the purification procedures depends on the limits of detection (LOD) and on the limits of quantification (LOQ) which are intended to be reached.

Extractions with ethyl acetate have been widely used (Rovira et al., 1993; Sydenham et al., 1995; Tsao \& Zhou, 2000; Kawashima et al., 2002). Iha \& Sabino (2006) applied mixtures of ethyl acetate and hexanes in the extraction step. In some cases, a procedure of depectinization is necessary before the extraction (Boonzaaijer et al., 2005; Spadaro et al., 2007). In the official method for determination of this toxin by liquid chromatography described in the AOAC (Association of Official Analytical Chemistry), item 995.10 (Brause et al., 1996), patulin is extracted three times with ethyl acetate followed by clean up with a sodium carbonate solution.

Purifications by solid phase extraction have been successfully used in recent years (Eisele \& Gibson, 2003; Lanças, 2004; Boonzaaijer et al., 2005; Li et al., 2007). Rovira et al. (1993) developed a methodology using silica cartridges for purification of the ethyl acetate extracts. Diphasic dialysis, a technique of extraction with membranes, was used in some studies (Prieta et al., 1994; Sheu \& Shyu, 1999). Another technique uses more conventional cartridges of reverse phase to retain the toxin. By this method, the apple juice is passed through a pre-conditioned cartridge containing copolymers of di-vinyl benzene and $\mathrm{N}$ vinylpyrrolidinone (Trucksess \& Tang, 1999). Columns of immunoaffinity (IAC), considered highly selective, cannot be used for extraction and purification of patulin because it is not possible to develop specific antibodies capable to recognize patulin separately (Dombrink-Kurtzman \& Blackburn, 2005).

\section{Detection and quantification}

In the analysis of apple tissues and derived products, the most common interfering agent is the 5-hydroxymethylfurfural (HMF), which affects the quantification of patulin. This interfering agent must be considered in the analytical methodologies used on a daily basis because, in general, HMF levels are two or three times higher than the levels of patulin normally detected. HMF is the product of dehydration of keto-pentoses in low $\mathrm{pH}$ or at high temperatures which may occur during food processing or storage (Lansalot-Matras \& Moreau, 2003). First, glucose or another hexose in acid media suffers isomerization at carbon one reducing group forming an isomer by the transfer of hydrogen of the $\mathrm{C} 2$ to the $\mathrm{C} 1$. In the sequence, dehydration and a formation of a hemiacetalic carbon-carbon bond between $\mathrm{C} 2$ and $\mathrm{C} 5$ yields the HMF (Porretta, 1992). The chemical structure of HMF is shown in Figure 2.

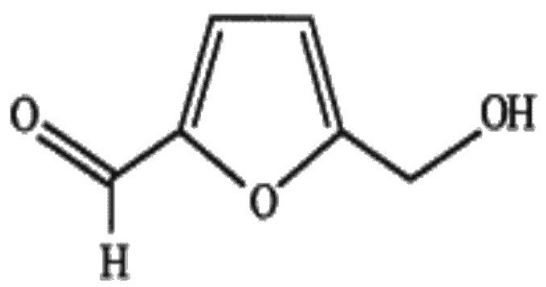

FIGURE 2 - Structure of HMF (5-Hydroxymethyl-2-furaldehyde).

For the determination of patulin, thin layer chromatography (TLC), mass spectroscopy connected to gas chromatography (CG/MS) and high performance liquid chromatography (HPLC) have been used. 


\section{Thin layer chromatography}

Thin layer chromatography (TLC) was the first method used for patulin determination in apple juices. The official AOAC method for the analysis of patulin by TLC was approved based on a study carried out by Scott (1974). This method involved the extraction with ethyl acetate and purification by a chromatographic column with silica gel. The detection in silica gel plates is observed by revelation with methyl-2benzothiazolinone hydrazone (MBTH). The limit of detection is 20 ì g.L. ${ }^{-1}$.

Two alternative methods for the quantification of patulin were reported as well. Leming et al. (1993) used the densitometry methodology to quantify the intensity of the points of patulin extracted from a matrix of corn. Durakovic et al. (1993) used fluorodensiometry after the formation of fluorescent derivatives obtained by exposition of the chromatographic points of patulin to ammonia vapor.

\section{High Performance Liquid Chromatography}

Due to the natural polarity of the patulin molecule and its strong characteristic of absorption of UV light, analytical methods based on High Performance Liquid Chromatography (HPLC) with reverse phase connected to the ultraviolet detector are extensively used. These methods have offered good results for the separation and quantification of patulin and HMF simultaneously with an ultraviolet detector from 280 to $272 \mathrm{~nm}$. However, the presence of interfering peaks turns the identification more difficult, resulting being necessary several steps of pre-treatment of the samples turning the process slow and expensive. Mass spectrometry and diode-array have also been used as a complement for the UV detection (Bartolomé et al., 1994; Gökmen \& Acar, 1999; Sewram et al., 2000; Shephard \& Leggott, 2000; Kawashima et al., 2002; Boonzaaijer et al., 2005; Gökmen et al., 2005).

In liquid chromatography, the identification and quantification are carried out by comparison with known quantities of the respective standards. In the methodology described in the AOAC, item 995.10 (Brause et al., 1996), patulin is extracted with an ethyl acetate and sodium bicarbonate solution. After evaporation of the organic solvent, patulin is determined by HPLC using $\mathrm{C}-18$ reverse phase column, with an UV detector.

Patulin is a low molecular weight and highly polar molecule, and can be removed from reverse phase columns by using a mobile phase with high percentage of water. The mobile phases used in the majority of the analyses are mixtures of acetonitrile and water at different ratios (Rovira et al., 1993; Sewram et al., 2000). Mixtures of water-ethanol, water-methanol-acetic acid have also been used (Bartolomé et al., 1994; Iha \& Sabino, 2006). HPLC is in general, operated without volume variation in the mobile phase (Sydenham et al., 1995).

\section{Capillary electrophoresis}

Capillary micellar electrokinetic chromatography (MECC) is a modern separation technique reported by Terabe et al. (1984) by modification of a capillary electrophoresis method that until then was only applied for separation of charged solutions. This technique involves the introduction of surfactants as dodecyl sodium sulfate (DSS). The micelles formed in solution constitute the pseudo-stationary phase.

The MECC system of separation is similar to a partition column of liquid chromatography, except for the stationary phase moving throughout the column; however, in a slower speed than the mobile phase (Foley, 1990). The mechanism of separation depends on the difference of coefficients of distribution of the analites between the aqueous phase and pseudo-stationary phase (Terabe, 1989).

The advantage that MECC presents in relation to HPLC is the fact of the change in the second phase involves only changes on micelles composition of the buffer, whereas in the HPLC it is necessary to change the stationary phase of the column. Another advantage is that MECC requires small volumes of samples, in the order of 0.1 to $10 \mathrm{~nL}$, and the number or theoretical plates are in the range of 100 to 200 thousand comparing to 5 to 20 thousand typical of HPLC (Skoog et al., 2002).

Tsao \& Zhou (2000) tested the analysis of patulin in apples using capillary electrophoresis for detection and quantification of this toxin. This method showed to be efficient and economically feasible using a small amount of sample and with a limit of detection of $3.8 \mu \mathrm{g} \cdot \mathrm{L}^{-1}$. However, the separation and identification of HMF interfering peak was not performed. Silva et al. (2007) developed a rapid method for simultaneous determination of HMF and patulin by MECC employing sodium dodecyl sulphate as anionic surfactant. The detection limits for HMF and patulin were $30 \mu \mathrm{g} . \mathrm{L}^{-1}$ and $9 \mu \mathrm{g} . \mathrm{L}^{-1}$, respectively. This method was successfully applied to the simultaneous determination of the analites in samples of apple juices.

\section{Confirmation}

The confirmation of patulin can be performed by mass spectrometry after separation and identification by liquid chromatography. This method generally involves the mass spectrometry or the formation of trimethylsilyl ether derivate with detection by electron capture. Depending on the detector used, this transformation is not necessary (Shephard \& Leggott, 2000; Rychlik \& Schieberle, 2001). Tarter \& Scott (1991) reported the preparation of heptafluorobutyrate (HBF) derivate of imidazole. The detection limit was below $10 \mu \mathrm{g} \cdot \mathrm{L}^{-1}$.

The mass spectrometry method supplies information regarding the mass and molecular structure of chemical compounds. This method has a high sensitivity and possibility to detect compounds in extremely low concentrations, as well as 
for the heterogeneity of its applications. The most sensitive GC detectors are of electron capture (ECD) and mass spectrometry (MS) The interfacement of the masses detector (MS) with gas chromatography (GC) results in a highly applicable method of chromatography. The interfaces were created to eliminate the high volume of solvent without eliminating the sample. (Llovera et al., 1999; Roach et al., 2002).

More recently, methods involving molecular biology have been applied in the study of patulin. The use of Polymerase Chain Reaction (PCR) has attracted considerable attention of researchers. This method makes possible the detection of the presence of the gene IDH (isoepoxydon dehydrogenase) in the fungus that probably produces patulin. The detection of this gene, present in the pathway which leads to patulin biosynthesis, has the advantage to confirm the results of the traditional methodologies and might become a new strategy for identification of species that produce this toxic metabolite (Paterson et al., 2000; Edwards et al., 2002; Marek et al., 2003; Haughland et al., 2004; Dombrink-Kurtzman \& Engberg, 2006; Russell \& Paterson, 2006; White et al., 2006).

A microarray for the analysis of the regulation of biosynthesis genes of patulin and other mycotoxins has been developed by Schmidt-Heydt \& Geise (2007). Initial application of this microarray demonstrates that it can be used to study the influence of growth parameters on the regulation of the genes and that it can be applied to detect mycotoxin biosynthesis gene mRNA in natural food environments. This approach offers new possibilities to study the influence of environmental parameters like substrate, $\mathrm{pH}$, temperature and water activity on the activation of the mycotoxin biosynthesis genes and thereby on mycotoxin biosynthesis.

\section{FINAL CONSIDERATIONS AND TRENDS FOR THE FUTURE}

Food science is growing significantly in recent years, as result of the increasing number of consumers concerned with food quality and safety. As a consequence, more powerful, clean and cheap analytical procedures are demanded by the quality control agencies. The evaluation on the contamination with patulin in apple and apple juices becomes an important factor to guarantee the quality of the fruit and its processed products.

Several methods to determine and quantify patulin in different foods have been developed, such as TLC, GC/MS and HPLC. Liquid chromatography with UV detector has turned to be the most successful method applied to identify and quantify patulin. Several improvements have been made in the last few years; however, the sensitivity of these methods is still a limiting factor. Currently, there are no fast and efficient analysis methods available. The official methodology requires sophisticated instrumentation and very well qualified work.

Trends for the future include the development of faster and more precise methods. Capillary micellar electrokinetic chromatography might well fulfill that purpose. This technique requires small volumes of samples, is faster than HPLC, and is environmentally safe, employing aqueous buffer. Moreover, the MECC apparatus is cheaper than the HPLC equipment.

Studies involving molecular biology are promising in the identification of the fungus and detection of patulin producing genes. The PCR technique allows the detection of the IDH gene, which is present in the pathway of patulin biosynthesis, and is a new strategy for identification of species that produce this toxic metabolite.

For a complete assessment of the mycotoxicological status of foods, the knowledge about the ability of the fungus to activate mycotoxin biosynthesis genes under the environmental conditions is also important. It has been shown that a microarray is suitable for the analysis of the activation of biosynthesis genes of most relevant mycotoxins, including patulin, under various conditions. It can be used in further work to analyse the influence of relevant parameters on pathway gene expression.

\section{ACKNOWLEDGMENTS}

The authors thank to CNPq for the financial support.

\section{REFERENCES}

ALTMAYER, B.; EICHHORN, K.W.; PLAPP, R. Untersuchungen über den Patulingehalt von Traubenmosten und Wein. Zeitschrift für Lebensmittel untersuchung und -Forschung A, Berlin, v.175, n.3, p.172-174, 1982.

ALVES, I. et al. Induction of micronuclei and chromosomal aberrations by the mycotoxin patulin in mammalian cells: role of ascorbic acid as a modulator of patulin clastogenicity. Mutagenesis, Oxford, v.15, n.3, p.229-234, 2000.

BAERT, K. et al. Free and bound patulin in cloudy apple juice. Food Chemistry, Barking, v.100, n.3, p.1278-1282, 2007.

BARTOLOMÉ, B. et al. Determination of patulin in apple juice by high-performance liquid chromatography with diode-array detection. Journal of Chromatography A, Amsterdam, v.664, n.1, p.39-43, 1994.

BENNETT, J. W. Mycotoxin,mycotoxicoses, mycotoxicoly and mycopathologia. Mycopathologia, Dordrecht, v.100, n.1, p.3$5,1987$.

BENNETT, J.W.; KLICH, M. Mycotoxins. Clinical Microbiology Reviews, Washington, v.16, n.3, p.497-516, 2003.

BISSESSUR, J.; PERMAUL, K.; ODHAV, B. Reduction of patulin during apple juice clarification. Journal of Food Protection, Des Moines, v.64, n.8, p.1216-1219, 2001.

BOONZAAIJER, G.; BOBELDIJK, I.; VAN OSENBRUGGEN, W.A. 
Analysis of patulin in Dutch food, an evaluation of a SPE based method. Food Control, Oxford, v.16, n.7, p.587-591, 2005.

BRACKETT, R. E.; MARTH, E. H. Ascorbic acid and ascorbate cause disappearance of patulin from buffer solutions and apple juice. Journal of Food Protection, Des Moines, v.42, n.11, p.864-866, 1979.

BRAUSE, A.R. et al. Determination of patulin in apple juice by liquid chromatography: collaborative study. Journal of AOAC International, Gaithersburg, v.79, n.2, p.451-455, 1996.

DHINGRA, O.D.; COELHO NETO, R.A. Micotoxinas em grãos. Revisão Anual de Patologia de Plantas, Passo Fundo, v.6, n.1,p.49-101, 1998.

DOMBRINK-KURTZMAN, M.A.; BLACKBURN, J.A. Evaluation of several culture media for production of patulin by Penicillium species. International Journal of Food Microbiology, Amsterdam, v.98, n.3, p.241-248, 2005.

DOMBRINK-KURTZMAN, M.A.; ENGBERG, A. Byssochlamys nivea with patulin-producing capability has an isoepoxydon dehydrogenase gene (idh) with sequence homology to Penicillium expansum and P. griseofulvum. Mycological Research, Cambridge, v.110, n.9, p.1111-1118, 2006.

DRUSCH, S.; KOPKA, S.; KAEDING, J. Stability of patulin in a juice-like aqueous model system in the presence of ascorbic acid. Food Chemistry, Barking, v.100, n.1, p.192-197, 2007.

DURAKOVIC, S. et al. The determination of patulin in apple juice. Arhiv Za Higijenu Rada I Toksikologiju, Zagreb v.44, n.3, p.263-268, 1993.

EDWARDS, S.G.; O'CALLAGHAN, J.; DOBSON, A.D.W. PCRbased detection and quantification of mycotoxigenic fungi. Mycological Research, Cambridge, v.106, p.1005-1025, 2002.

EISELE, T.A.; GIBSON, M.Z. Syringe-cartridge solid-phase extraction method for patulin in apple juice. Journal of AOAC International, Gaithersburg, v.86, n.6, p.1160-1163, 2003.

FAO - FOOD AND AGRICULTURE ORGANIZATION OF THE UNITED NATIONS. FAOSTAT - Agricultural statistics database. 2006. Disponível em: <http://faostat.fao.org>. Acesso em: 02 abr. 2007.

FLIEGHE, R.; METZLER, M. Electrophilic Properties of Patulin. N-Acetylcysteine and Glutathione Adducts. Chemical Research in Toxicology, Washington, v.13, n.5, p.373-381, 2000.

FOLEY, J. P. Optimization of Micellar Electrokinetic Chromatography. Analytical Chemistry, Washington, v.62, n.13,p.1302-, 1990.

FRANK, H.K. Occurrence of patulin in fruit and vegetables. Annales de la Nutrition et de l'Alimentation, Paris, v.31, p. 459-465, 1977.

FRANK, H.R.; ORTH, R.; FIGGE, A. Patulin in Lebensmitteln pllanzlicher Herkunft. Zeitschrift für Lebensmitteluntersuchung und -Forschung A, Heidelberg, v.163, p.111-114, 1977.

GÖKMEN, V.; ACAR, J. Simultaneous determination of 5hydroxymethylfurfural and patulin in apple juice by reversedphase liquid chromatography. Journal of Chromatography A, Amsterdam, v.847, n.1-2, p.69-74, 1999.

GÖKMEN, V.; ACAR, J.; SARIOĐLU, K. Liquid chromatographic method for the determination of patulin in apple juice using solid-phase extraction. Analytica Chimica Acta, Amsterdam, v.543, n.1-2, p.64-69, 2005.

HASAN, H.A.H. Patulin and aflatoxin in brown rot lesion of apple fruits and their regulation. World Journal of Microbiology \& Biotechnology, London, v.16, n.7, p.607-612, 2000.

HAUGHLAND, R.A. et al. Quantitative PCR analysis of selected Aspergillus, Penicillium and Paecilomyces species. Systematic and Applied Micriobiology, Stuttgart, v.27, n.2, p.198-210, 2004.

HUEBNER, H.J. et al. Development and characterization of a carbon-based composite material for reducing patulin levels in apple juice. Journal of Food Protection, Des Moines, v.63, n.1,p.106-110, 2000.

IBGE. SIDRA (Sistema IBGE de Recuperação Automática) Banco de Dados Agregados. On-line. Disponível em: $<$ w w w . s idra.ibge.gov.br/bda/a cervo/ acervo2.asp? $\mathrm{e}=\mathrm{v} \& \mathrm{p}=\mathrm{PA} \& \mathrm{z}=\mathrm{t} \& \mathrm{o}=10>$. Acesso em: $29 \mathrm{mar}$. 2007.

IHA, M.H.; SABINO, M. Determination of patulin in apple juice by liquid chromatography. Journal of AOAC International, Gaithersburg, v.89, n.1, p.139-143, 2006.

JACKSON, L.S et al. Apple Quality, Storage, and Washing Treatments Affect Patulin Levels in Apple Cider. Journal of Food Protection, Des Moines, v.66, n.4, p.618-624, 2003.

KAWASHIMA, L.M.; SOARES, L.M.V.; MASSAGUER, P.R. The development of an analytical method for two mycotoxins, patulin and verruculogen, and survey of their presence in commercial tomato pulp. Brazilian Journal of Microbiology, São Paulo, v.33, p.269-273, 2002.

KREUZ, C. L.; ARGENTA, L. C. O uso do 1-MCP para a geração de valor na cadeia produtiva da maçã. Revista da Agropecuária Catarinense, Florianópolis, v.16. n. 2, p. 59-62, 2003.

LANÇAS, F.M. Extração em fase sólida. São Paulo: RiMa, 2004. p. 96.

LANSALOT-MATRAS, C.; MOREAU, C. Dehydration of fructose into 5-hydroxymethylfurfural in the presence of ionic liquids. Catalysis Communications, Berlin, v.4, n.10, p.517520, 2003.

LEMING, L. et al. Simultaneous thin layer chromatographic determination of zearalenone and patulin in maize. Journal of Planar Chromatography - Modern TLC, Budakalász, v.6, n.4, p.271-277, 1993.

LI, J. et al. Solid-phase extraction and HPLC determination of patulin in apple juice concentrate. Food Control, Oxford, v.18, n.5, p.530-534, 2007.

LLOVERA, M. et al. Analysis of underivatizated patulin by a GCMS technique. Journal of Food Protection, Des Moines, v.62, n.2, p.202-205, 1999

MACHINSKI, M.; MIDIO, A.F. Incidencia de patulina en jugo de manzana industrializado. Alimentaria, Madrid, v.276, p.6164, 1996.

MAHFOUD, R. et al. The mycotoxin patulin alters the barrier function of the intestinal epithelium: mechanism of action of the toxin and protective effects of glutathione. Toxicology and Applied Pharmacology, Raleigh, v.181, n.3, p.209-218, 2002.

MAREK, P.; ANNAMALAI, T.; VENKITANARAYANAN, K. Detection of Penicillium expansum by polymerase chain 
reaction. Journal of Food Microbiology, Amsterdam, v.89, n.23,p.139-144, 2003.

MCKINLEY, E.R.; CARLTON, W.W.; BOON, G.D. Patulin mycotoxicosis in the rat: toxicology, pathology and clinical pathology. Food and Chemical Toxicology, Elmsford, v.20, n.3, p.289-300, 1982.

PATERSON, R.R.M. et al. A gene probe for the patulin metabolic pathway with potential for use in patulin and novel disease control. Biocontrol Science and Technology, New York, v.10, n.4, p.509-512, 2000.

PORRETTA, S. Chromatographic analysis of Maillard reaction products. Journal of Chromatography A, Amsterdam, v.624, n.1/2, p.211-219, 1992.

PRADO, G. et al. Ocorrência de patulina em suco de maçã por cromatografia líquida de alta eficiência. Revista do Instituto Adolfo Lutz, São Paulo, v.59, n.1/2, p.21-25, 2000.

PRIETA, J. et al. Survey of patulin in apple juice and children's apple food by the diphasic dialysis membrane procedure. Journal of Agricultural and Food Chemistry, Washington, v.42, n.8, p.1701-1703, 1994.

ROACH, J.A. et al. HPLC detection of patulin in apple juice with GC/MS confirmation of patulin identity. Advances in Experimental Medicine and Biology, New York, v.504, p.135$140,2002$.

ROLAND, J. O.; BEUCHAT, L. R. Biomass and patulin production by Byssochlamys nivea in apple juice as affected by sorbate, benzoate, $\mathrm{SO}_{2}$ and temperature. Journal of Food Science, Chicago, v.49, n.2, p.402-406, 1984.

ROSS, G.U. et al. Produção de patulina em maçã (Malus domestica Borkhausen), cultivares Gala e Fuji inoculadas com Penicillium spp. Ciência e Tecnologia de Alimentos, Campinas, v.18, n.1, p.63-67, 1998.

ROVIRA, R. et al. Improvements in the quantitation of patulin in apple juice by high-performance liquid chromatography. Journal of Agricultural and Food Chemistry, Washington, v.41, n.2, p.214-216, 1993.

RUSSELL, R. et al. Solutions to Penicillium taxonomy crucial to mycotoxin research and health. Research in Microbiology, Paris, v.155, n.7, p.507-513, 2004.

RUSSELL, R.; PATERSON, M. Primers from the isoepoxydon dehydrogenase gene of the patulin biosynthetic pathway to indicate critical control points for patulin contamination of apples. Food Control, Oxford, v.17, n.9, p.741-744, 2006.

RYCHLIK, M.; SCHIEBERLE, P. Model studies on the diffusion behavior of the mycotoxin patulin in apples, tomatoes, and wheat bread. European Food Research Technology, Berlin, v.212, n.3, p.274-278, 2001.

SANHUEZA, R.M.V. Apresentação: Importância da cultura. Em: EMBRAPA UVA E VINHO. Produção Integrada de Maçã. Sistemas de Produção, 1. Versão Eletrônica. 2003. Disponível em: <www.cnpuv.embrapa.br/publica/sprod/ ProducaoIntegradaMaca/index.htm>. Acesso em: 02 abr. 2007.

SCHMIDT-HEYDT, M.; GEISE, R. A microarray for monitoring the production of mycotoxins in food. International Journal of Food Microbiology, Amsterdan, v.117, n.2, p.131-140, 2007

SCHUMACHER, D. M. et al. DNA-DNA cross-links contribute to the mutagenic potential of the mycotoxin
patulin.Toxicology Letters, Shannon, v.166, n.3, p.268-275, 2006.

SCOTT, P.M. Collaborative study of a chromatographic method for determination of patulin apple juice. Journal of AOAC International, Gaitherburg, v.57, n.3, p.621-625, 1974.

SELMANOGLU, G. Evaluation of the reproductive toxicity of patulin in growing male rats. Food and Chemical Toxicology, Elmsford, v.44, n.12, p.2019-2024, 2006.

SEWRAM, V. et al. Determination of patulin in apple juice by high-performance liquid chromatography-atmospheric pressure chemical ionization mass spectrometry. Journal of Chromatography A, Amsterdam, v.897, n.1-2, p.365-374, 2000.

SHEPHARD, G.S.; LEGGOTT, N. L. Chromatographic determination of the mycotoxin patulin in fruit and fruit juices. Journal of Chromatography A, Amsterdam, v.882, n.1-2, p.17-22, 2000.

SHEU, F.; SHYU, Y.T. Analysis of Patulin in Apple Juice by Diphasic Dialysis Extraction with in Situ Acylation and Mass Spectrometric Determination. Journal of Agricultural and Food Chemistry, Washington, v.47, n.7, p.2711-2714, 1999.

SILVA, S.J.N.; SCHUCH, P.Z.; JABLONSKI, A. Determinação simultânea de 5-hidroximetilfurfural e patulina em suco de maçã por eletrocromatografia micelar. Higiene Alimentar, São Paulo, v.21, n.155, 2007.

SKOOG, D.A.; HOLLER, F.J.; NIEMAN, T.A. Princípios de análise instrumental. 5. ed. Porto Alegre: Bookmann, 2002. 836p.

SPADARO, D. et al. Incidence and level of patulin contamination in pure and mixed apple juices marketed in Italy. Food Control, Oxford, v.18, n.9, p.1098-1102, 2007.

SPEIJERS, G. J. A. Patulin. In: MAGAN, N.; OLSEN, M. (Ed.). Mycotoxins in food: detection and control. Cambridge: Woodhead Publishing, 2004. p.339-52.

SPEIJERS, G.J.; FRANKEN, M.A.; VAN LEEUWEN, F.X. Sub acute toxicity study of patulin in the rat: Effects on the kidney and the gastro-intestinal tract. Food and Chemical Toxicology, Oxford, v.26, n.1, p.23-30, 1988.

STRAY H. High press liquid chromatography method for the determination of patulin in apple juice. Journal of the Association of Official Analytical Chemists, Arlington, v.61, n.6, p.1359-1362, 1978.

SYDENHAM,. E.W. et al. Reduction of patulin in apple juice samples: influence of initial processing. Food Control, Oxford, v.6, n.4, p.195-200, 1995.

SYLOS, C.M.D.; RODRIGUEZ-AMAYA, D. B. Incidence of patulin in fruits and fruit juices marketed in Campinas, Brazil. Food Additives and Contaminants, London, v.16, n.2, p.71-74, 1999.

TANIWAKI, M.H. et al. Migration of patulin in apples. Journal of Food Protection, Des Moines, v.55, n. 11, p.902-904, 1992.

TARTER, E. J.; SCOTT, P.M. Determination of patulin by capillary gas chromatography of the heptafluorobutyrate derivative. Journal of Chromatography A, Amsterdam, v.538, n.2, p.441446, 1991.

TERABE, S. Electrokinetic's chromatography: an interface between electrophoresis and chromatography. TrAC Trends in Analytical Chemistry, Amsterdam v.8, n.4, p.129-134, 1989.

TERABE, S. et al. Electrokinetic's separations with micellar solutions and open-tubular capillaries. Analytical Chemistry, Washington, v.56, n.1, p.111-113, 1984. 
TRUCKSESS, M.W.; TANG, Y. Solid-phase extraction method for patulin in apple juice and unfiltered apple juice. Journal of AOAC International, Gaithersburg, v.82, n.5, p.1109-1113, 1999.

TSAO, R.; ZHOU, T. Micellar Electrokinetic's Capillary Electrophoresis for Rapid Analysis of Patulin in Apple Cider. Journal of Agricultural and Food Chemistry, Washington, v.48, n.11, p.5231-5235, 2000.

WHITE, S.; O'CALLAGHAN, J.; DOBSON, A.D.W. Cloning and molecular characterization of Penicillium expansum genes upregulated under conditions permissive for patulin biosynthesis. FEMS Microbiology Letters, Amsterdan, v.255, n.1,p.17-26, 2006

WHO - Joint FAO/WHO Expert Committee on Food Additives (JECFA). Position paper on patulin. 30th session. The Hague,. 1998.

WU, T. et al. Activation of ERK mitogen-activated protein kinase in human cells by the mycotoxin patulin. Toxicology and Applied Pharmacology, Orlando, v.207, n.2, p.103-111, 2005.

YAZICI, S.; VELIOGLU, Y.S. Effect of thiamine hydrochloride, pyridoxine hydrochloride and calcium-d-pantothenate on the patulin content of apple juice concentrate. Nahrung, Weinheim, v.46, n.4, p.256-257, 2002.

ZEGOTA, H.; ZEGOTA, A.; BACHMAN, S. Effect of irradiation and storage on patulin disappearance and some chemical constituents of apple juice concentrate. Zeitschrift für Lebensmitteluntersuchung und -Forschung A,_Heidelberg, v.187, n.4, p.321-324, 1988. 